\title{
The Laurentian Neoproterozoic Glacial Interval: reappraising the extent and timing of glaciation
}

\author{
Daniel Paul LE HERON ${ }^{1{ }^{*}}$, Nicholas EYLES') \& Marie Elen BUSFIELDD \\ ${ }^{1)}$ Department for Geodynamics and Sedimentology, Althanstraße 14, University of Vienna, 1090 Vienna. \\ ${ }^{2)}$ Department of Physical and Environmental Sciences, University of Toronto at Scarborough, 1265 Military Trail, Scarborough, ON, Canada M1C 1A4. \\ 3) Department of Geography and Earth Sciences, Llandinam Building, Aberystwyth University, SY23 3DB, United Kingdom \\ *) Corresponding author, daniel.le-heron@univie.ac.at
}

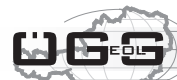

KEYWORDS Cryogenian, glaciation, tectonics, Snowball Earth, Neoproterozoic

\begin{abstract}
One of the major issues in Neoproterozoic geology is the extent to which glaciations in the Cryogenian and Ediacaran periods were global in extent and synchronous or regional in extent and diachronous. A similarly outstanding concern is determining whether deposits are truly glacial, as opposed to gravitationally initiated mass flow deposits in the context of a rifting Rodinia supercontinent. In this paper, we present 115 publically available, quality-filtered chronostratigraphic constraints on the age and duration of Neoproterozoic glacial successions, and compare their palaeocontinental distribution. Depositional ages from North America (Laurentia) clearly support the idea of a substantial glacial epoch between about 720-660 Ma on this palaeocontinent but paradoxically, the majority of Australian glacial strata plot outside the previously proposed global time band for the eponymous Sturtian glaciation, with new dates from China also plotting in a time window previously thought to be an interglacial. For the early Cryogenian, the data permit either a short, sharp 2.4 Ma long global glaciation, or diachronous shifting of ice centres across the Rodinia palaeocontinent, implying regional rather than global ice covers and asynchronous glacial cycles. Thus, based on careful consideration of age constraints, we suggest that strata deposited in the ca. 720-660 Ma window in North America are better described as belonging to a Laurentian Neoproterozoic Glacial Interval (LNGl), given that use of the term Sturtian for a major Neoproterozoic glacial epoch can clearly no longer be justified. This finding is of fundamental importance for reconstructing the Neoproterozoic climate system because chronological constraints do not support the concept of a synchronous panglacial Snowball Earth. Diachroneity of the glacial record reflects underlying palaeotectonic and palaeogeographic controls on the timing of glaciation resulting from the progressive breakup of the Rodinian supercontinent.
\end{abstract}

\section{Introduction}

In 2020, the idea of globally synchronous Snowball Earth events during the Cryogenian period (Hoffman et al., 1998; Hoffman and Schrag, 2002) remains a popular idea. The expansion of global scale ice masses excites many geologists, and the notion is now used to explain phenomena such as regional or even global scale unconformities (DeLucia et al., 2018) and patterns of biological evolution (e.g., Brocks et al., 2017). Numerous studies advocate an older 720-660 Ma 'Sturtian' glaciation and a younger shorter-length 645-635 Ma 'Marinoan' glaciation, both named after Australian stratigraphy, and both defined by globally synchronous onsets and terminations (Hoffman and Schrag, 2002). Looking at the development of ideas of global glaciation, Eyles and Januszczak (2004) recognized five iterations of snowball Earth in the literature including (i) Agassiz (1840) for die Eiszeit, specifically dealing with the Quaternary, (ii) Ramsay's (1926) proposal of "worldwide refrigeration", (iii) Mawson's (1949) recognition of "the world's greatest ice age" in the Precambrian, (iv) Harland's "Infracambrian glaciation" with near synchronous global tillites (1964), and finally (v) the "modern snowball" theory of Kirschvink (1992) and Hoffman et al. (1998). Between these times, skepticism for glaciation has waxed and waned, and the intensity and extent of glaciation has come under scrutiny. Two fundamental aspects are (i) geochronology and (ii) the systematic and detailed evaluation of sedimentary facies. Robust dates are required to support the idea of a global glaciation: with 'the decisive falsifying test' of a Snowball Earth model being chronometry (Hoffman 2011, p. 29). Furthermore, careful and systematic analysis of sedimentary sections and their palaeotectonic setting during deposition is essential to demonstrate the glacial, interglacial, or non-glacial origins of the successions (Allen and Etienne, 2008).

Using Re-Os geochrononology, Rooney et al. (2014) argued that the longest and oldest such Neoproterozoic glaciation (the Sturtian: Macdonald et al., 2010) was of $55 \mathrm{Ma}$ duration, based on sample analyses immediately below and above the Rapitan diamictite of Canada. The use of stable isotope curves is widely used as a correlation tool where absolute dates are not available 
(e.g Halverson et al., 2010). Allen and Etienne (2008) provocatively proposed that absolute age dates from glacial sequences could be interpreted as recording 6 local phases of glaciation between 780 and 630 million years, based on 14 global radiometric age constraints, recognizing that this was a non-unique solution. The idea of diachroneity in Neoproterozoic glaciations is not new: Kröner (1977) made this claim for African deposits, albeit based on a limited set of Rb-Sr ages.

A major problem with the objective interpretation of Neoproterozoic glaciations, and glacial deposits associated with them, is that discussion is dominated by the model-led approach of Snowball Earth (Hoffman et al., 2017). A specific problem seems to be the tendency to neglect sedimentological details that the model cannot accommodate, and yet which demand rational geological explanation (see, for example: Condon et al., 2002; Arnaud, 2004; Leather et al., 2005; Allen and Etienne, 2008; Le Heron et al., 2011, 2013, Busfield and Le Heron, 2016, 2018). When problems with the model arise, inconvenient evidence is typically not tackled head-on, should this evidence be incompatible. This approach has led to continual adaptation of the hypothesis to new evidence (Allen and Etienne, 2008). It is in this context in which we reappraise the chronometry of the Neoproterozoic glaciations, identify alternative interpretations that honour the available data, and consider the extent to which glacial successions of this age can be confidently correlated on a global basis.

The core of our paper is 115 age constraints which are presented from publically available, peer-reviewed sources, which have been sub-divided on a palaeocontinent-by-palaeocontinent basis (Fig. 1). We propose two plausible explanations of the global geochronological dataset: (i) a short, sharp (2.4 Ma long) glaciation in the early Cryogenian, in direct contrast to prevailing views for a 55 Ma glaciation, and (ii) regionally diachronous glaciations similar to those previously proposed (e.g. Eyles and Januszczak, 2004). Both of these explanations are distinct from both the Snowball and Slushball models (see Fairchild and Kennedy, 2007, for a review). The issue of diachroneity and correlation is also discussed, as is the correlation potential of glacial successions.

\section{Data and methods}

Spence et al. (2016) published the global geochronological constraints on Proterozoic glacial deposits up to December 2015. Mining those data herein, and combining them with data published since, we plotted 115 individual data points on a continent-by-continent basis, showing maximum, minimum, and depositional ages for such units (Fig. 1). Data from abstracts and extended abstracts were discarded due to lack of evidenced scrutiny and peer-review. This approach resolves the issue of so-called "rumourchrons" or situations where two or more versions of the same age constraint are publically available (typically resulting from data or sample reprocessing between conference abstract submission and the associated peer-reviewed paper emerging subsequently). Using the same reasoning, we have also discarded dates from secondary sources, i.e. those papers relying on age data published in abstracts only. On the plot, we display error bars for each point and also colour-code the geochronometric data source (Re-Os, U-Pb TIMS, U-Pb SHRIMP, $\mathrm{PbPb}$ TIMS, paired U-Pb and Lu-Hf, K-Ar, Rb-Sr, Ar-Ar hornblende, Sm-Nd Th-U-Pb and Sm-Nd). Geochronological constraints are available from nine discrete regions (Sao Francisco / Congo Craton, Kalahari Craton, North China, South China, Arabia / Nubia, Australia, Laurentia, Avalonia and West Africa). These are widely regarded as tectonically separate entities during the Neoproterozoic (Li et al., 2013). Throughout this paper the temporal duration of proposed snowball Earth intervals follows the scheme of Rooney et al. (2015).

\subsection{Data descriptions}

The following descriptions refer exclusively to Fig. 1. With a single exception (Cox et al., 2018), it is apparent that all Australian data points fall outside the proposed "Sturtian" panglacial time band of Rooney et al. (2015). Indeed, aside from two data points in South China (Lan et al., 2014; Zhou et al., 2004: points 6 and 7 respectively, South China bin), a single data point in Oman (Bowring et al., 2007: point 10, Arabia/Nubia bin- incorporating resampled material of Brasier et al., 2000), and one in Mongolia (Rooney et al., 2015: point 31, Laurentia bin), the only continent that demonstrably yields "Sturtian" age dates is Laurentia. There, a swathe of maximum age constraints (mostly from U-Pb TIMS zircon dates) cluster in the 780720 Ma time window; some depositional ages are provided by ash beds (Fanning and Link, 2004; Lund et al., 2003). The youngest date from the "Sturtian" in North America is 662.4 $\pm 4.6 \mathrm{Ma}$ (Rooney et al., 2014). It is also evident that no dates of "Sturtian" age are evident from the Kalahari, North China, Avalonia or West African cratons despite the supposed globally-synchronous extent of that glaciation (Hoffman, 2011 and refs therein). It is immediately apparent that North American rocks provide the firmest age constraints on Neoproterozoic glaciation (particularly Canada: Rooney et al., 2014).

In Australia, depositional ages extend from the end of the Sturtian to the beginning of the Marinoan as defined by Rooney et al. (2015). In China, Zhou et al. (2004) reported a syn-depositional age of $662.9 \pm 4.3 \mathrm{Ma}$ from an ash bed in the Datangpo Formation below the Nantuo glacial deposits, arguing for a Marinoan age. The plot shows that this date (point 8 in the South China bin) is much older than the contact between the supposedly Sturtian glacial deposits and the Tindelpina Shale in the Flinders Ranges based on the syn-depositional, Re-Os analyses of Kendall et al. $2006(643.0 \pm 2.4 \mathrm{Ma})$ (point 7 in the Australia bin).

On the Arabia / Nubia palaeocontinent, the syn-depositional 711.5 $\pm 0.3 \mathrm{Ma}$ age (Bowring et al., 2007: Arabia / Nubia bin, point 10) is particularly noteworthy as occurring very early in the Sturtian, which seems problematic in the framework of a Snowball Earth model where the 
bulk of sedimentation is predicted to occur during final deglaciation under a warming climate (Allen and Etienne, 2008). Moreover, the felsic ash beds that yield this date occur deep in the Abu Mahara stratigraphy beneath a thick succession of intercalated glacial diamictites and non-glacial siliciclastics (Allen and Etienne, 2008).

\subsection{Data interpretation}

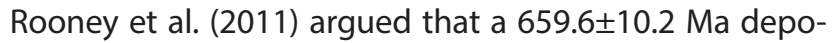
sitional age for pre-glacial Ballachulish Slate in Scotland (point 25, Laurentia bin, Fig. 1) "strongly suggests that the Port Askaig Formation may be correlative with the $\sim 650 \mathrm{Ma}$ end-Sturtian glaciations of Australia". By direct comparison, a Re-Os age of 657.2 \pm 5.4 Ma was provided by Kendall et al. (2006) for the basal postglacial shales of the Aralka Formation in central Australia, who also obtained another age of $643.0 \pm 2.4 \mathrm{Ma}$ from the lithostratigraphically equivalent Tindelpina Shale Member in South Australia. Appraising the global data set, a panglacial of just 2.4 Ma in duration could thus be proposed (whereby 659.6-657.2= 2.4 Ma), a very short "flash in the pan" glaciation contrasting with the $58 \mathrm{Ma}$ duration proposed elsewhere (Cox et al., 2018). This very short time span contrasts vividly with the established, widely-held view of a long-lived Sturtian panglaciation (Macdonald et al., 2010; Rooney et al., 2014, Hoffman et al., 2017, Cox et al., 2018) on multiple continents and oceans (Rooney et al., 2015). However, given the absence of depositional ages from within the posited 55 Ma glaciation time window (Fig. 1), an equally credible interpretation is that there simply are no glacial deposits belonging to the "Sturtian" time band as defined in Rooney et al. (2014) in Australia.

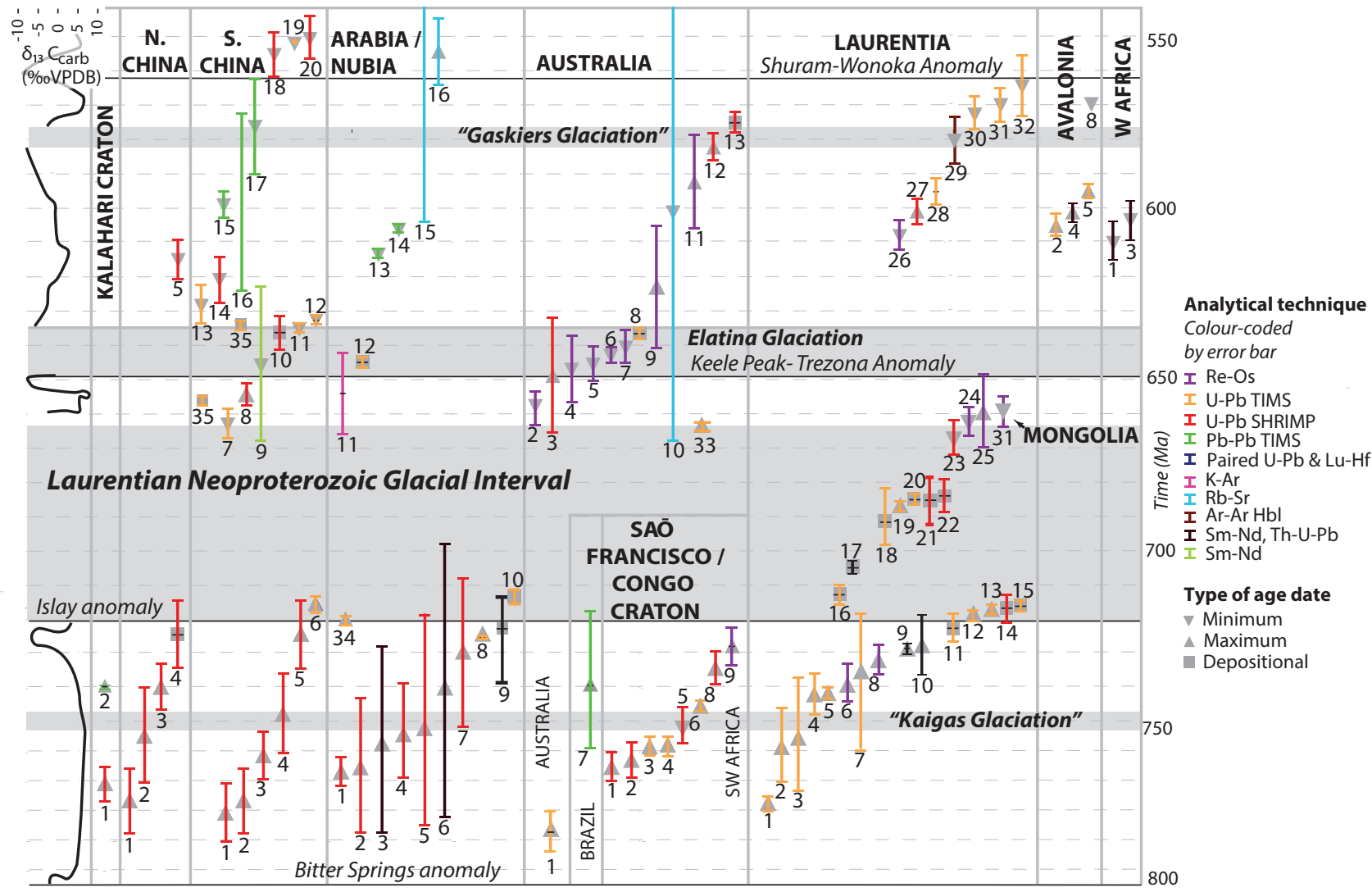

Fig. 1. Plot showing available ages of Neoproterozoic diamictites determined through a variety of different methods and plotted according to Neoproterozoic continental blocks / cratons. Data sources as follows. AVALONIA AND WEST AFRICA: (1) Lahondère et al. (2005); (2) Krogh et al. (1988); (3) Lahondère et al. (2005); (4) Kaye et al. (1980); (5) Thompson et al. (2000); (8) Thompson and Bowring (2000). LAURENTIA: (1) Jefferson et al. (1989); (2, 30, 32) Aleinikoff et al. (1995); (3) Ross and Villeneuve (1997); (4) Kalstrom et al. (2000); (5) Fetter and Goldberg (1995); (6) Strauss et al. (2014); (7) McDonough and Parrish (1991); (8, 24) Rooney et al. (2014); (9) Tollo and Aleinikoff (1996); (10) Evenchick et al. (1984); (11) Heaman et al. (1992); (12) Cox et al. (2015); $(13,15)$ Macdonald et al. (2010); (14, 23) Fanning and Link (2004); (16) Denyszyn et al. (2009); (17) Tollo and Aleinkoff (1996); (18) Ferri et al. (1999); (19) Condon and Bowring (2011); (20) Keeley et al. (2013); (21, 22) Lund et al. (2003); (25) Rooney et al. (2011); (26) Kendall et al. (2004); (17) Dempster et al. (2002); (28) Halliday et al. (1989); (29) Link et al. (1993); (30) Colpron et al. (2002). AUSTRALIA: (1) Preiss et al. (2009); (2, 4, 5, 6) Kendall et al. (2006); (3) Ireland et al. (1998); (7) Kendall et al. (2009); (8) Calver et al. (2013); (9, 11) Schaefer and Burgess (2003); (10) Preiss (1987); (12, 13) Calver et al. (2004); (33) Cox et al. (2018). ARABIA / NUBIA: $(1,2,4,5,7)$ Ali et al. (2010); (3, 6) Tadesse et al. (2000); (8, 10, 12) Bowring et al. (2007); (9) Brasier et al. (2000); (11) Gorin et al. (1982); (13, 14) Miller et al. $(2003)$; $(15,16)$ Dureuilh et al. (1992); (34) MacLennan et al. (2018) SAO FRANCISCO, CONGO: (1) Key et al. (2001); (2) Key et al. (2001); (3) Halverson et al. (2005); (4) Hoffman et al. (1996); (5) Borg et al. (2003); (6) Hoffman et al. (1996); (7) Babinski et al. (2007); (8) Key et al. (2001); (9) Rooney et al. (2015). KALAHARI: (1) Frimmel et al. (2001), (2) Frimmel et al. (1996) NORTH CHINA: (1) Yin et al. (2005); (2) Xu et al. (2005); (3, 4, 5) Xu et al. (2009). SOUTH CHINA: (2, 3, 22) Yin et al. (2005); (4) Li et al. (2003); (5) Ma et al. (1984); (7) Zhang et al. (2008); (8) Lan et al. (2014); (9) Zhou et al. (2004); (10, 12) Zhang et al. (2008); (11) Yang et al. (1994); (13, 14, 21) Condon et al. (2005); (15) Yin et al. (2005); (16, 20) Zhang et al. (2005); (17) Barfod et al. (2002); (18) Chen et al. (2004); (19) Chen et al. (2004); (35) Zhou et al. (2019) 
Paradoxically, the data indicate that there is much stronger geochronological evidence for "Sturtian" (sensu Rooney et al., 2014) time band deposits in North America (Laurentia) than in Australia, where only a single depositional age (Cox et al., 2018; point 31 in the Australia bin on Fig. 1) plots toward the very top of the "Sturtian" time window. At least five major tectonic events associated with the breakup of Rodinia are now recognized in the plate tectonic models of Merdith et al. (2017), which can be summarized as follows. These are (i) displacement of the Congo-São Francisco cratons between ca. 850$800 \mathrm{Ma}$, (ii) initial Rodinia breakup in the window 800$750 \mathrm{Ma}$, (iii) rifting of the Congo-São Francisco cratons at 750-700 Ma, (iv) Kalahari rifting at 700-600 Ma, and (v) opening of the lapetus from ca. $600 \mathrm{Ma}$. Thus, the interval containing abundant evidence for glaciation continues to be recognized as one characterized by protracted, pulsed rifting and supercontinent fragmentation, as emphasized in the Zipper Rift hypothesis (Eyles and Januszczak, 2004) where accommodation (and thus depositional ages) are controlled by tectonics. Specifically, the clustering of depositional age dates in the 780-720 Ma time window is consistent with initial Rodinia rifting and rift basin formation, and the potentially continuing far field effects of the Congo-São Francisco craton breakup thereafter (Merdith et al., 2017).

The above analysis leads to the conclusion that the continued use of the term "Sturtian" to refer to a major worldwide glacial interval can no longer be justified. It has been long since pointed out that the term Sturtian was applied to a specific chronostratigraphic subdivision in the Adelaide fold belt of South Australia (see Preiss et al., 2011 for a review), because it contained, among other rocks, the deposits of Sturt Gorge outside of Adelaide (Mawson and Sprigg 1950). Owing to the current lack of a GSSP for the Cryogenian, which may be resolved in the near future (Shields et al., 2018), we feel it is currently inappropriate to try to establish further formal terminology to apply to events or glaciations within the Cryogenian period on the basis of supposed global synchroneity of glaciation. It is recommended that the term "Sturtian" should now be applied only to the appropriate rocks of Australia. In the meantime, to avoid the potential for confusion, we advocate the informal term "Laurentian Neoproterozoic Glacial Interval" (LNGI) to describe the episode of glaciation recorded in and affecting North America, and loosely comparable to the Sturtian time band in Rooney et al. (2015). This informal term is appropriate because it refers to well-studied glacial deposits from which there are a series of independent age constraints, and does not include reference to problematic rocks for which few age constraints are available.

\section{Discussion and implications}

The current drive to find a suitable Global Section Stratotype and Point (GSSP) for the Cryogenian (Shields et al., 2018), renders the discussion of the extent and posited synchronicity (e.g. Rooney et al., 2015, Cox et al., 2018) of
Cryogenian glaciations very pertinent. To many, this is an uncomfortable discussion given the neat two-fold Sturtian and Marinoan glaciations which are popularly proposed (Evans, 2000). This two-fold subdivision has long been shown on publications (Hoffman et al., 2017), even however when those publications plot age constraints with wide error bars (Evans, 2000). The plots presented here, in contrast, permit alternative interpretations that are faithful to the data in 2020. Two plausible alternatives adequately explain the global trends seen on this plot. The first is one of a short, sharp older Cryogenian glaciation of 2.4 Ma in duration; the second model proposes a diachronous older Cryogenian glaciation that is best expressed on Laurentia, the Laurentian Neoproterozoic Glacial Interval (LNGI) proposed here. Owing to the need to "force fit" data from multiple continents to a "Sturtian" model, we place the short, sharp glacial model to one side. The recognition of an LNGI is significant for a number of reasons. Firstly, the Laurentian record provides excellent age constraints from the Yukon (Rooney et al., 2015). Secondly, alongside the Port Askaig Formation (in Scotland), and the Danzhou Group (China), Shields et al. (2018) identify the Kingston Peak Formation of Death Valley- one of the best Laurentian diamictite outcrop belts in terms of exposure- as having potential as a GSSP. Note that the analysis herein does not exclude the existence of other regional glaciations occurring within the LNGI time window.

Deposits of the LNGI contain persuasive evidence for glacially-influenced marine sedimentation in multiple basins. The Port Askaig Formation contains abundant dolostone lonestones in laminated mudstone (Fig. 2A) that are best interpreted as ice-rafted dropstones (Ali et al., 2018). On mainland Scotland, granite dropstones punctuating and piercing laminated mudstones and sandstones attain boulder size (Fig. 2B) in the Macduff Boulder Beds. In Utah, the Mineral Fork Formation represents the approximate stratigraphic equivalent of the Kingston Peak Formation and exposes exquisite dropstones on Antelope Island (Fig. 2 C). Other intervals of massive diamictite from the same formation (Fig. 2D) are much more ambiguous.

The most demonstrative evidence for both glaciation and tectonics is found in the Kingston Peak Formation of Death Valley, California, which provides a number of excellent lessons for understanding the true relationship between Neoproterozoic glaciation and extensional basin tectonics. Here, evidence of a tectonic control on glaciation becomes evident at a number of scales. At the same time, there are a number of diamictite-rich/bearing sections, at multiple stratigraphic intervals, which are commonly assumed to be glaciogenic but can be demonstrated to derive from local slope collapse. In the Saddle Peak Hills (Fig. 2E) some diamictites are interpreted as platform collapse facies (Creveling et al., 2016; Le Heron and Vandyk, 2019) rather than of glacial origin. This is because the abundant dolomite clasts contain very peculiar facies including tubestone structures and laminites that are restricted to cap carbonate deposits, illustrating that diamictites and the Noonday Dolomite 

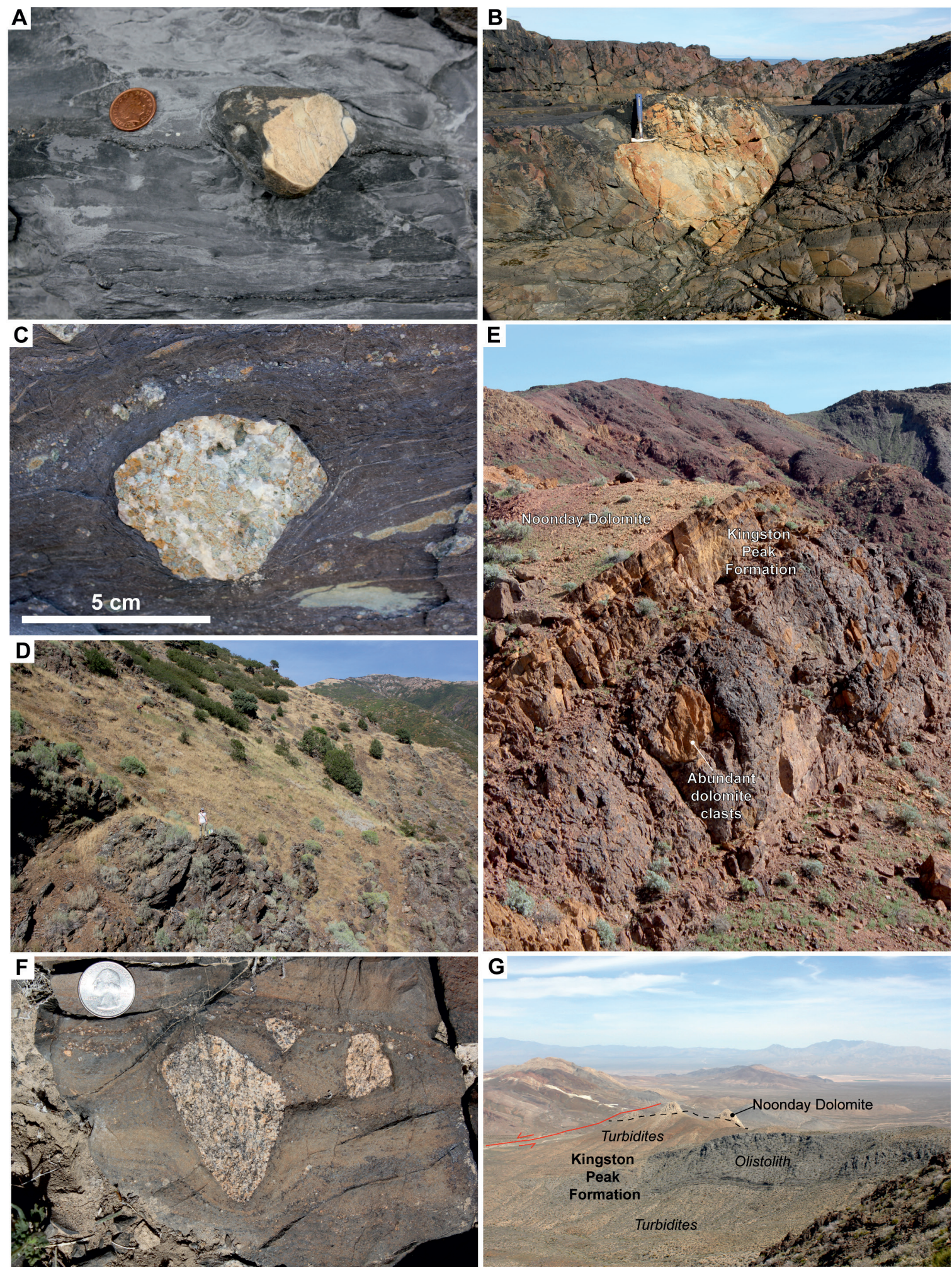

Fig. 2. Examples of glacial and non-glacial facies from diverse Laurentian outcrops associated with the Laurentian Neoproterozoic Glacial Interval (LNGI). A: Dolostone lonestone, interpreted as a dropstone, from the Port Askaig Formation, Garbh Eilach, Scotland. This formation records dozens of ice margin oscillations (Ali et al., 2018). B: Granite boulder from the Macduff Boulder Beds, northern Scotland. These deposits represent ice distal sedimentation, with occasional emplacement of ice rafted debris in a marine basin (Busfield and Le Heron, 2018). C: Granite lonestone, interpreted as a dropstone, from the Mineral Fork Formation, Antelope Island, Utah. D: Thick, stacked, boulder-rich diamictites from the Pocatello Formation, Idaho. Though a lateral continuation of the Mineral Fork Formation, their origin (glacial vs non-glacial) remains ambiguous. E: The contact between diamictites of the Kingston Peak Formation and the overlying Noonday Dolomite in the Saddle Peak Hills, Death Valley. These particular diamictites are known to contain fragments of carbonate laminites and tubestones- an identical facies that is exposed in the overlying Noonday Dolomite (Creveling et al., 2016). F: More convincing evidence for a glacial influence on sedimentation from the Salt Spring Hills, Death Valley, also from the Kingston Peak Formation. Trains of lonestones, interpreted as dropstones, are well exposed. G: Scale of observation greatly affecting perspective in the Kingston Peak Formation in the Kingston Range type area. A $500 \mathrm{~m}$ wide dolostone block derived from underlying strata is encased within turbidites, and interpreted as an olistolith (Macdonald et al., 2013, Le Heron et al., 2014). 
are laterally equivalent facies (Creveling et al., 2016). The same story is played out in the type section in the Kingston Range, where huge megaclasts interpreted as olistoliths (Macdonald et al., 2013; Le Heron et al., 2014) are encased in well-organised turbidites with occasional dropstone-bearing intervals (Fig. 2G). Nevertheless, there are abundant sections where excellent dropstones are recognized (Busfield \& Le Heron, 2016; Le Heron \& Busfield, 2016), and where glacial influence on sedimentation is beyond reasonable doubt (Fig. 2F). In spite of this, there remains a paradox concerning the rate of sediment supply. Attempts to quantify accumulation rates associated with Cryogenian glaciations have led to the conclusion that Cryogenian accumulation rates were 4 to 15 times slower than for comparable Phanerozoic glaciations (Partin and Sadler, 2016). These conclusions provide fertile ground for considering ice dynamics, yet they are underpinned by an assumption of $5 \mathrm{Myr}$ and 57 Myr durations for the Marinoan and Sturtian glaciations respectively. Even if a global, "Sturtian" glaciation is dismissed and the LNGI recognised instead, then it remains unchanged that sedimentation rates were low.

In the context of the LNGl, detailed investigation of the Kingston Peak Formation in Death Valley from multiple outcrop belts (Fig. 3) has revealed how variable the diamictite-bearing deposits are, recording multiple glacial cycles that cannot be correlated between individual basins (Le Heron et al., 2017, 2019). This is thought to be because the ice masses waxed and waned asynchronously, and deposited a record intimately mixed with tectonically driven slope collapse debris and olistostromes (Le Heron et al., 2019). In this regard, Kennedy and Eyles (2020) emphasize the importance of tectonically-driven basin margin collapse and mass flow events in generating debrites previous reported as 'glacial diamictites' and 'tillites' that are non-glacial 'tectonofacies' produced by downslope mixing of coarse and fine sediment. These workers emphasized the importance of applying a 'tectonosequence' approach in contrast to the simple bedby-bed climatostratigraphic models of earlier workers. Other investigations in Congo has similarly demonstrated the fundamental importance of a tectonic driver on facies types in Neoproterozoic rift basin fills, especially in promoting the accumulation of the 'diamictite/turbidite association' that is characteristic of this interval globally where diamictites commonly approach $1 \mathrm{~km}$ in thickness (Kennedy et al., 2018; Kennedy and Eyles, 2019). This work also demonstrates that comparison of very detailed sedimentary logs in terms of facies, clast composition and stratigraphic stacking patterns permit no correlation whatsoever even over a few hundred metres (Tofaif et al., 2019), with major implications for identifying "type sites".

Fig. 3. Logged sections from both the Silurian Hills and Kingston Range outcrop belts in the Death Valley region, from Le Heron et al. (2019). Log from the Silurian Hills originally published in Le Heron et al. (2017), and log from the Kingston Range originally published in Le Heron et al. (2018). The comparison highlights that correlation is impossible between neighbouring sub-basins.

\section{A: Southern Kingston Range B: Silurian Hills}

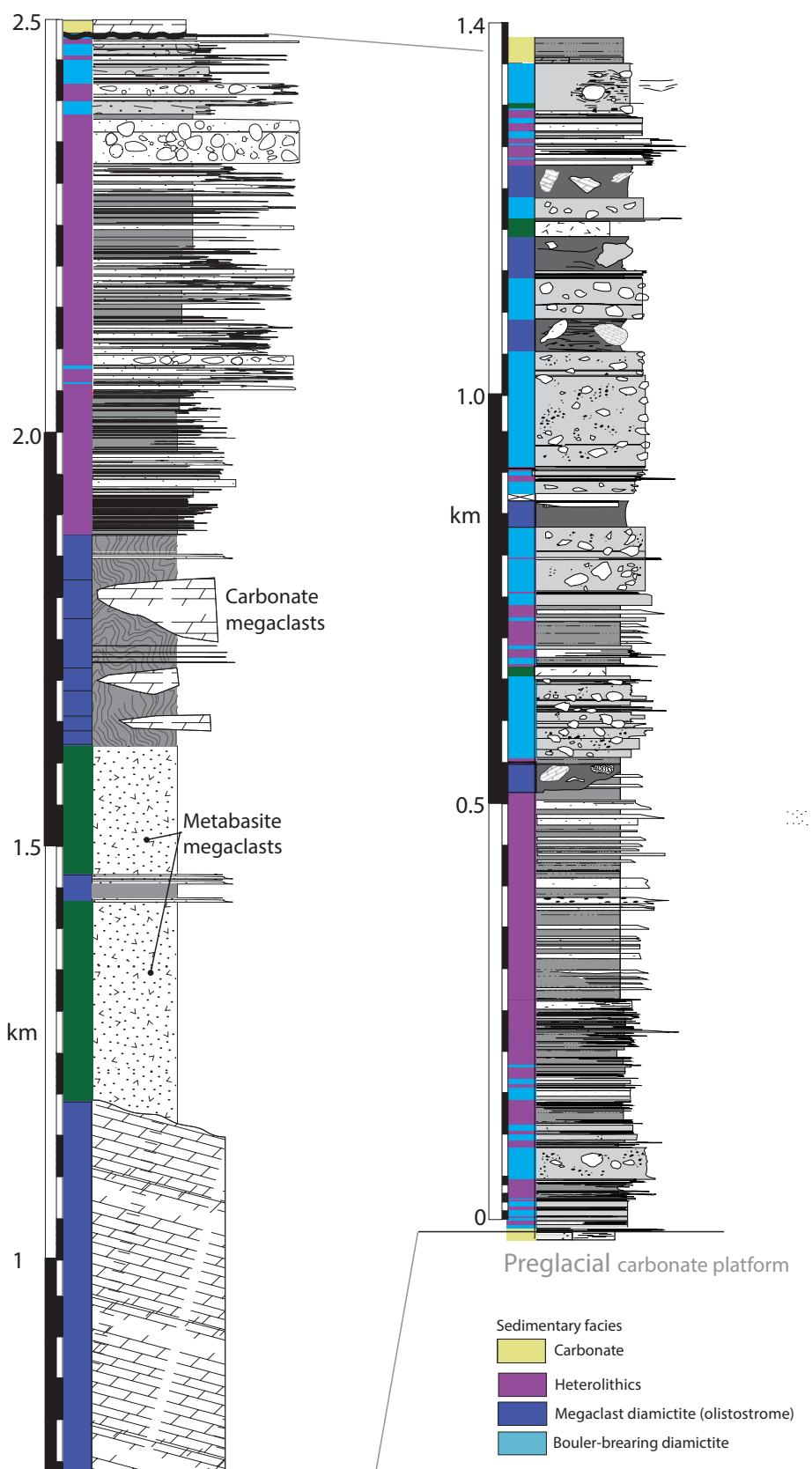

Lithologies

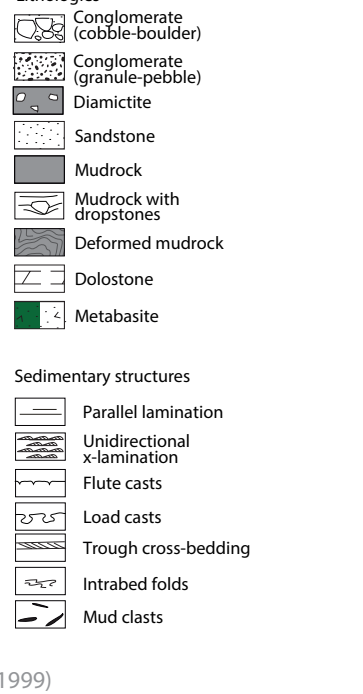


With their basis in detailed sedimentological work and consideration of the local basinal setting, the above considerations underscore how the long-suspected intimate association between rifting and glaciation in Death Valley (Prave, 1999) is correct, how these processes conspire to produce a differing record between sub-basins, and how they allow specific questions to be raised about representativeness of the Cryogenian record. These questions extend to all areas on Earth where Neoproterozoic sedimentary successions are exposed. The importance of tectonically driven mass flow sedimentation in the Grand Conglomérat of the Congo Basin has now been recognized in which the primary evidence for glaciation is weak (Kennedy et al., 2018). Arguably the greatest issue is how to evaluate the significance of glacial cycles in the rock record. Further afield, in South Australia, Busfield and Le Heron (2014) demonstrated the applicability of sequence stratigraphy to unravel the nature of glacial cycles in the Cryogenian record, leveraging the glacial sequence stratigraphic methodology of Powell and Cooper (2002) that had been developed for temperate glaciated margins. This methodology is appropriate owing to the apparent lack of syn-sedimentary tectonism in this study area. Other examples, such as the Port Askaig Formation in Scotland, may also be suitable for this approach. In the Port Askaig, no less than 28 glacial cycles (Ali et al., 2018) are recognized, raising serious questions about how, if at all, these cycles can be correlated across palaeocontinents. Establishing which of these cycles represents major glaciation, as opposed to minor ice margin oscillation, remains a goal that is currently out of reach. Coupled with the clear influence of tectonics in compartmentalizing extensional basins, it is suggested that meaningful correlation at an interbasinal level is premature. These stratigraphic and sedimentological considerations underpin the view that the geochronological data must be interpreted more openly to understand the nature, extent, and intensity of glaciation.

\section{Conclusions}

Based on review of the available peer-reviewed geochronological database, we suggest that older Cryogenian glaciations are asynchronous, amplifying the earlier interpretations of Allen and Etienne (2008). In 2020, the available evidence supports a model of diachroneity and provinciality in Neoproterozoic glaciations, and an interpretation that indicates that the Snowball Earth hypothesis can now be objectively placed aside. Diachroneity reflects underlying palaeotectonic and palaeogeographic controls on the timing of glaciation associated with the progressive breakup of the Rodinian supercontinent (Eyles and Januszczak, 2004; Merdith et al., 2017). We propose that the term "Sturtian" should now be used exclusively for the Australian strata, because it derives from Australian sections where chronometry remains poor in spite of recent progress (Cox et al., 2018). Instead, we suggest that the term Laurentian Neoproterozoic Glacial Interval (LNGI) is adopted, which refers to a regional but well constrained interval in present day North America between 720 and $660 \mathrm{Ma}$.

\section{Acknowledgments}

This manuscript was originally written and submitted in 2016, where it received a large number of anonymous reviews at various stages. We are thankful to all colleagues who have provided input into what still seems to be quite a controversial topic. For the final manuscript, we are grateful to Nicole Januszczak and to a further anonymous colleague for useful and constructive comments and to Walter Kurz for handling the paper.

\section{References}

Agassiz, L., 1840, Études sur les glaciers. Neuchâtel. Jent et Gassmann.

Aleinikoff, J.N., Zartman, R.E., Walter, M., Rankin, D.W., Lyttle, P.T., Burton, W.C., 1995. U-Pb ages of metarhyolites of the Catoctin and Mount Rogers Formation, central and southern Appalachians: evidence for two pulses of lapetan Rifting. American Journal of Science, 295, 428454. https:// doi: 10.2475/ajs.295.4.428

Ali, D.O., Spencer, A.M., Fairchild, I.J., Chew, K.J., Anderton, R., Levell, B.K., Hambrey, M.J., Dove, D., Le Heron, D.P., 2018. Indicators of relative completeness of the glacial record of the Port Askaig Formation, Garvellach Islands, Scotland. Precambrian Research, 319, 69-78. https://doi. org/10.1016/j.precamres.2017.12.005

Ali, K.A., Stern, R.J., Manton, W.I., Kimura, J.I., Khamees, H.A., 2009. Geochemistry, $\mathrm{Nd}$ isotopes and U-Pb SHRIMP zircon dating of Neoproterozoic volcanic rocks from Central Eastern Desert of Egypt: New insights into the $\sim 750 \mathrm{Ma}$ crust-forming events. Precambrian Research, 171, 1-22. https://doi.org/10.1016/j.precamres.2009.03.002

Ali, K.A., Stern, R.J., Manton, W.I., Johnson, P.R., Mukherjee, S.K., 2010. Neoproterozoic diamictite in the Eastern Desert of Egypt and Northern Saudi Arabia: Evidence of $\sim 750$ Ma glaciation in the Arabian-Nubian Shield? International Journal of Earth Sciences, 99, 705-726. https:// doi.org/10.1007/s00531-009-0427-3

Allen, P.A., Etienne, J.L., 2008. Sedimentary challenge to Snowball Earth: Nature Geoscience, 1, 817-825. https:// doi.org/10.1038/ngeo355

Arnaud, E., 2004. Giant cross-beds in the Neoproterozoic Port Askaig Formation, Scotland: Implications for snowball Earth. Sedimentary Geology, 165, 155-174. https:// doi.org/10.1016/j.sedgeo.2003.11.015

Babinski, M., Vieira, L.C., Trindade, R.I.F., 2007. Direct dating of the Sete Lagoas cap carbonate (Bambuí Group, Brazil) and implications for the Neoproterozoic glacial events. Terra Nova, 19, 401-406. https://doi.org/10.1111/j.13653121.2007.00764.x

Barfod, G.H., Albarede, F., Knoll, A.H., Xiao, S., Télouk, P., Frei, $\mathrm{P} .$, J., 2002. New Lu-Hf and $\mathrm{Pb}-\mathrm{Pb}$ age constraints on the earliest animal fossils. Earth and Planetary Science Letters, 201, 203-212. https://doi.org/10.1016/S0012$821 \times(02) 00687-8$ 
Borg, G., Kärner, K., Buxton, M., Armstrong, R., Merwe, S.W.V.D., 2003. Geology of Skorpion supergene zinc deposit Southern Namibia. Economic Geology, 98, 749-771. https://doi.org/10.2113/gsecongeo.98.4.749

Bowring, S.A., Grotzinger, J.P., Condon, D.J., Ramezani, J., Newall, M.J., Allen, P.A., 2007. Geochronological constraints on the chronostratigraphic framework of the Neoproterozoic Huqf Supergroup, Sultanate of Oman. American Journal of Science, 307, 1097-1145. https://doi. org/10.2475/10.2007.01

Brasier, M., McCarron, G., Tucker, R., Leather, J., Allen, P.A., Shields, G., 2000. New U-PB zircon ages for the Neoproterozic Ghubrah glaciations and for the top of the Huqf Supergroup, Oman. Geology, 28, 175-178. https://doi.org/ 10.1130/0091-7613(2000)28<175:NUZDFT>2.0.CO;2

Brocks, J.J., Jarrett, A.J.M., Sirantoine, E., Hallmann, C., Hoshino, Y., Liyange, T., 2017. The rise of algae in Cryogenian oceans and the emergence of animals. Nature, 548, 578581. https://doi.org/10.1038/nature23457

Busfield, M.E., Le Heron, D.P., 2014. Sequencing the Sturtian icehouse: dynamic ice behavior in South Australia. Journal of the Geological Society of London 171, 443-456. https:// doi.org/10.1144/jgs2013-067

Busfield, M.E., Le Heron, D.P., 2016. A Neoproterozoic ice advance sequence, Sperry Wash, California. Sedimentology, 63, 307-330. https://doi.org/10.1111/sed.12210

Busfield, M.E., Le Heron, D.P., 2018. Snowball Earth under the microscope. Journal of Sedimentary Research, 88, 659-677. https://doi.org/10.2110/jsr.2018.34

Calver, C.R., Black, L.P., Everard, J.L., Seymour, D.B., 2004. $\mathrm{U}-\mathrm{Pb}$ zircon age constraints on late Neoproterozoic glaciation in Tasmania. Geology, 32, 893-896. https://doi. org/10.1130/G20713.1

Calver, C.R., Crowley, J.L., Wingate, M.T.D., Evans, D.A.D., Raub, T.D., Schmitz, M.D., 2013. Globally synchronous Marinoan deglaciation indicated by $\mathrm{U}-\mathrm{Pb}$ geochronology of the Cottons Breccia, Tasmania, Australia. Geology, 41, 1127-1130. https://doi.org/10.1130/G34568.1

Chen, D.F., Dong, W.Q., Zhu, B.Q., Chen, X.P., 2004. Pb-Pb ages of the Neoproterozoic Doushantuo phosphorites in South China: constraints on early metazoan evolution and glacial events. Precambrian Research, 132, 123-132. https://doi.org/10.1016/j.precamres.2004.02.005

Coleman, A.P., 1926. Ice Ages: Recent and Ancient. Macmillan, London, 296 pp. https://doi.org/10.1038/118293a0

Colpron, M., Logan, J.M., Mortensen, J.K., 2002. U-Pb zircon age constraints for late Neoproterozoic rifting and initiation of the lower Paleozoic passive margin of western Laurentia. Canadian Journal of Earth Sciences, 39, 133-143. https://doi.org/10.1139/e01-069

Condon, D.J., Prave, A.R., Benn, D.I., 2002. Neoproterozoic glacial-rainout intervals: Observations and implications. Geology, 30, 35-38. https://doi. org/10.1130/0091-7613(2002)030<0035:NGRIOA > 2.0.CO;2 Condon, D.J., Zhu, M., Bowring, S., Wang, W., Yang, A., Jin, Y., 2005. U-Pb ages from the Neoproterozoic Doushantuo Formation. Chin. Sci., 308, 95-98. https://doi/10.1126/science. 1107765
Condon, D.J., Bowring, S.A., 2011. Chapter 9: A user's guide to Neoproterozoic geochronology. Geological Society of London, Memoirs, 36, 135-149. https://doi.org/10.1144/ M36.9

Cox, G.M., Strauss, J.V., Halverson, G.P., Schmitz, M.D., McClelland, W.C., Stevenson, R.S., Macdonald, F.A., 2015. Kikiktat volcanics of Arctic Alaska-Melting of harzburgitic mantle associated with the Franklin Large Igneous Province. Lithosphere, 7, 275-295. https://doi/ 10.1130/L435.1 Cox, G.M., Isakson, V., Hoffman, P.F., Gernon, T.M., Schmitz, M.D., Shahin, S., Collins, A.S., Preiss, W., Blades, M.L., Mitchell, R.N., Nordsvan, A., 2018. South Australian U-Pb zircon (CA-ID-TIMS) age supports globally synchronous Sturtian deglaciation. Precambrian Research, 315, 257-263. https://doi.org/10.1016/j.precamres.2018.07.007

Creveling, J. R., Bergmann, K. D., Grotzinger, J. P., 2016. Cap carbonate platform facies model, Noonday Formation, SE California. Geological Society of America Bulletin, 128, 1249-1269.

DeLucia, M.S., Guenthner, W.R., Marshak, S., Thomson, S.N., Ault, A.K., 2018. Thermochronology links denudation of the Great Unconformity surface to the supercontinent cycle and snowball Earth. Geology, 46, 167-170. https://doi. org/10.1130/G39525.1

Dempster, T.J., Rogers, G., Tanner, P.W.G., Bluck, B.J., Muir, R.J., Redwood, S.D., Ireland, T.R., Paterson, B.A., 2002. Timing of deposition, orogenesis and glaciation within the Dalradian rocks of Scotland; constraints from $\mathrm{U}-\mathrm{Pb}$ zircon ages. Journal of the Geological Society of London, 159, 83-94. https://doi.org/10.1144/0016-764901061

Denyszyn, S.W., Davis, D.W., Hall, H.C., 2009. Paleomagnetisum and $\mathrm{U}-\mathrm{Pb}$ geochronology of the Clarence Head dykes, Artic Canada: Orthogonal emplacement of mafic dykes in a large igneous province. Canadian Journal of Earth Sciences, 46, 155-167. https://doi.org/10.1139/E09-011

Dubreuilh, J.M., Platel, P., Le Metour, J., Roger, J., Wyns, R., Bechennec, F., Berthiaux, A., 1992. Geological map of Khaluf, 1: 250 000, sheet NF 40-15. Bureau de Recherches géologiques et minières, Orléans, France.

Evans, D.A.D., 2000, Stratigraphic, Geochronological, and Paleomagnetic constraints upon the Neoproterozoic climatic paradox. American Journal of Science, 300, 347-433. https://doi/ 10.2475/ajs.300.5.347

Evenchick, C.A., Parrish, R.R., Gabrielse, H., 1984. Precambrian gneiss and Proterozoic sedimentation in north-central British Columbia. Geology, 12, 233-237. https://doi. org/10.1130/0091-7613(1984)12<233:PGALPS>2.0.CO;2

Eyles, N., Januszczak, N., 2004. 'Zipper-rift': A tectonic model for Neoproterozoic glaciations during the breakup of Rodinia after $750 \mathrm{Ma}$. Earth-Science Reviews, 65, 1-73. https://doi.org/10.1016/S0012-8252(03)00080-1

Fanning, C.M., Link, P.K., 2004. U-Pb SHRIMP ages of Neoproterozoic (Sturtian) glaciogenic Pocatello Formation, southeastern Idaho. Geology, 10, 881-884. https://doi. org/10.1130/G20609.1

Ferri, F., Rees, C.J., Nelson, J.L., Legun, A.S., 1999. Geology and mineral deposits of the northern Kechika Trough 
between Gataga River and the 60th parallel. British Columbia Ministry of Energy and Mines, Bulletin, 107, 1-22.

Fetter, A.H., Goldberg, S.A., 1995. Age and geochemical characteristics of the bimodal magmatism in the Neoproterozoic Grandfather Mountain rift basin. Journal of Geology, 103, 313-326. https://doi/10.1086/629749

Frimmel, H.E., Klötzli, U.S., Siegfried, P.R., 1996. New Pb-Pb single zircon age constraints on the timing of Neoproterozoic glaciation and continental break-up in Namibia. Journal of Geology, 104, 459-469. http://doi/10.1086/629839

Frimmel, H.E., Zartman, R.E., Späth, A., 2001. The Richtersveld Igneous Complex, South Africa: U-Pb Zircon and geochemical evidence for the beginning of Neoproterozoic continental breakup. Journal of Geology, 109, 493508. https://doi.org/10.1086/320795

Gorin, G.E., Racz, L.G., Walter, M.R., 1982. Late Precambian-Cambrian sediments of the Huqf Group, Sultanate of Oman. American Association of Petroleum Geologists Bulletin, 66, 2609-2627.

Halliday, A.N., Graham, C.M., Aftalion, M., Dymoke, P., 1989. The depositional age of the Dalradian Supergroup; U-Pb and Sm-Nd isotopic studies of the Tayvallich Volcanics, Scotland. Journal of the Geological Society of London, 146, 3-6. https://doi.org/10.1144/gsjgs.146.1.0003

Halverson, G.P., Wade, B.P., Hurtgen, M.T., Barovich, K.M., 2010. Neoproterozoic chemostratigraphy. Precambrian Research, 182, 337-350. https://doi/10.1016/j.precamres.2010.04.007

Harland, W.B., 1964. Critical evidence for a great infra-Cambrian glaciation. Geologisches Rundschau, 54, 45-61. https://doi.org/10.1007/BF01821169

Heaman, L.M., Le Cheminant, A.N., Rainbird, R.H., 1992. Nature and timing of the Franklin igneous events Canada: implications for a late Proterozoic mantle plume and break up of Laurentia. Earth and Planetary Science Letters, 109, 117-131. https://doi.org/10.1016/0012-821X(92)90078-A Hoffman, P.F., 2011. A history of Neoproterozoic glacial geology, 1871-1997. In: Arnaud, E., Halverson, G.P., ShieldsZhou, G. (eds.), The Geological Record of Neoproterozoic Glaciations. Geological Society, London, Memoir 36, 1737. https://doi.org/10.1144/M36.2

Hoffman, P.F., Hawkins, D.P., Isachsen, C.E., Bowring, S.A., 1996. Precise U-Pb zircon ages for early Damaran magmatism in the Summas mountains and Welwitschia inlier, northern Damara belt Namibia. Communications of the Geological Survey of Namibia, 11, 47-52.

Hoffman, P.F., Kaufman, A.J., Halverson, G.P., Schrag, D.P., 1998. A Neoproterozoic Snowball Earth. Science, 281, 1342-1346. 10.1126/science.281.5381.1342

Hoffman, P.F., Schrag, D.P., 2002. The snowball Earth hypothesis: Testing the limits of global change. Terra Nova, 14, 129-155. 10.1046/j.1365-3121.2002.00408.x

Hoffman, P.F., Abbot, D.S., Ashkenazy, Y., Benn, D.I., Brocks, J.J., Cohen, P.A., Cox, G.M., Creveling, J.R., Donnadieu, Y., Erwin, D.H., Fairchild, I.J., Ferreira, D., Goodman, J.C., Halverson, G.P., Jansen, M.F., Le Hir, G., Love, G.D., Macdonald, F.A., Maloof, A.C., Partin, C.A., Ramstein, G., Rose, B.E.J., Rose, C.V., Sadler, P.M., Tziperman, E., Voigt, A., Warren,
S.G., 2017. Snowball Earth climate dynamics and Cryogenian geology-geobiology. Sci. Adv. 3 (11), e1600983. https://doi/ 0.1126/sciadv.1600983

Fairchild, I.J., Kennedy, M.J., 2007. Neoproterozoic glaciation in the Earth System. Journal of the Geological Society, London, 164, 895-921. https://doi.org/10.1144/001676492006-191

Ireland, T.R., Flöttmann, T., Fanning, C.M., Gibson, G.M., Preiss, W.V., 1998. Development of the early Palaeozoic Pacific margin of Gondwana from detrital-zircon ages across the Delamerian orogeny. Geology, 26, 243-246. https://doi.or g/10.1130/0091-7613(1998)026<0243:DOTEPP >2.3.CO;2

Jefferson, C.W., Parrish, R.R., 1989. Late Proterozoic stratigraphy, U-Pb zircon ages, and rift tectonics, Mackenzie Mountains, northwestern Canada. Canadian Journal of Earth Science, 26, 1784-1801. https://doi.org/10.1139/ e89-151

Kalstrom, K.E., Bowring, S.A., Dehler, C.M., Knoll, A.H., Porter, S.M., Marais, D.J.D., Weil, A.B., Sharp, Z.D., Geissman, J.W., Elrick, M.B., Timmons, J.M., Crossey, L.J., Davidek, K.L., 2000. Chuar Group of the Grand Canyon: Record of breakup of Rodina, associated changes in the global carbon cycle, and ecosystem expansion by 740 Ma. Geology, 28, 619-622. https://doi/10.1130/0091-7613(2000)28<619:cgotgc $>2.0 . c 0 ; 2$

Kaye, C.A., Zartman, R.E., 1980. A Late Proterozoic to Cambrian age for the stratified rocks of the Boston Basin, Massachusetts, USA. In: Wones, D.R. (ed.), The Caledonides in the USA. Virginia Polytechnic Institute and State University Memoir, 2, 257-261.

Keeley, J.A., Link, P.K., Fanning, C.M., Schmitz, M.D., 2013. Pre- to synglacial rift-related volcanism in the Neoproterozoic (Cryogenian) Pocatello Formation, SE Idaho: New SHRIMP and CA-ID TIMS constraints. Lithosphere, 5, 128150. https://doi.org/10.1130/L226.1

Kendall, B.S., Creaser, R.A., Ross, G., Selby, D., 2004. Constraints on the timing of Marinoan "snowball Earth" glaciation by $187 \mathrm{Re}-1870$ s dating of a Neoproterozoic post glacial black shale in western Canada. Earth and Planetary Science Letters, 222, 729-740. https://doi.org/10.1016/j. epsl.2004.04.004

Kendall, B., Creaser, R.A., Selby, D., 2006. Re-Os geochronology of postglacial black shales in Australia: Constraints on the timing of "Sturtian" glaciations. Geology, 34, 729-732. https://doi.org/10.1130/G22775.1

Kendall, B., Creaser, R.A., Calver, C.R., Raub, T.B., Evans, D.A.D., 2009. Correlation of Sturtian diamictite successions in southern Australia and northwestern Tasmania by Re-Os black shale geochronology and the ambiguity of "Sturtian"-type diamictite-cap carbonate pairs as chronostratigraphic maker horizons. Precambrian Research, 172, 301310. https://doi.org/10.1016/j.precamres.2009.05.001

Kennedy, K., Eyles, N., Broughton, D., 2018. Basinal setting and origin of thick $(1.8 \mathrm{~km})$ mass flow dominated Grand Conglomérat diamictites, Kamoa, Democratic Republic of Congo: Resolving climate and tectonic controls during Neoproterozoic glaciations. Sedimentology, 66, 556-589. https://doi.org/10.1111/sed.12494 
Kennedy, K., Eyles, N., 2019. Subaqueous debrites of the Grand Conglomérat Formation, Democratic Republic of Congo: a model for anomalously thick Neoproterozoic 'glacial' diamictites. Journal of Sedimentary Research, 89, 1-21. https://doi.org/10.2110/jsr.2019.51

Kennedy, K., Eyles, N., 2020, Tectonically-generated debris flows and related mass-flow'tectonofacies' of the Neoproterozoic Kingston Peak Formation, Death Valley California. Sedimentology in press.

Key, R.M., Liyungu, A.K., Njamu, F.M., Somwe, V., Banda, J., Mosley, P.N., Armstrong, R.A., 2001. The western arm of Lufilian Arc in Zambia and its potential for copper mineralization. Journal of African Earth Science, 33, 503-528. https://doi.org/10.1016/S0899-5362(01)00098-7

Kirschvink, J.L., 1992. Late Proterozoic low-latitude glaciation: The snowball Earth. In: Schopf, J.W., Klein, C. (eds.), The Proterozoic biosphere. Cambridge University Press, Cambridge, 51-52.

Krogh, T.E., Strong, D.F., O'Brien, S.J., Papezik, V.S., 1988. Precise U-Pb zircon dates from the Avalon Terrane in Newfoundland. Canadian Journal of Earth Sciences, 25, 442453. https://doi.org/10.1139/e88-045

Kröner, A., 1977. Non-synchroneity of late Precambrian glaciations in Africa. Journal of Geology, 85, 289-300. https:// doi.org/10.1086/628300

Lahondère, D., Roger, J., Le Métour, J., Donzeau, M., Guillocheau, F., Helm, C., Thiéblemont, D., Cocherie, A., Guerrot, C., 2005. Notice explicative des cartes géologiques à $1 / 200.00$ et $1 / 500,000$ de l' extrème sud de la Mauritanie. DMG, Ministère des mines et de lindustrie, Nouakchott, Rapport BRGM/RC-54273-FR, 610.

Lan, Z., Li, X., Zhu, M., Chen, Z.-Q., Zhang, Q., Li, Q., Lu, D., Liu, Y., Tang, G., 2014. A rapid and synchronous initiation of the widespread Cryogenian glaciations. Precambrian Research, 255, 401-411. http://doi/ 10.1016/j.precamres.2014.10.015

Leather, J., Allen, P.A., Brasier, M.D., Cozzi, A., 2002. Neoproterozoic snowball Earth under scrutiny: Evidence from the Fiq glaciation of Oman. Geology, 30, 891-894. https://doi. org/10.1130/0091-7613(2002)030<0891:NSEUSE > 2.0.CO;2

Le Heron, D.P., Vandyk, T., 2019. A slippery slope for Cryogenian diamictites? The Depositional Record, 5, 306-321. https://doi.10.1002/dep2.67

Le Heron, D.P., Cox, G.M., Trundley, A.E., Collins, A. 2011. Sea ice free conditions during the Sturtian glaciation (early Cryogenian), South Australia. Geology, 39, 31-34. https:// doi.org/10.1130/G31547.1

Le Heron, D.P., Busfield, M.E., Kamona, A.F., 2013. Interglacial on snowball Earth? Dynamic ice behaviour revealed in the Chuos Formation, Namibia. Sedimentology, 60, 411-427. https://doi.org/10.1111/j.1365-3091.2012.01346.x

Le Heron, D.P., Tofaif, S., Vandyk, T., Ali, D.O., 2017. A diamictite dichotomy: glacial conveyor belts and olistostromes in the Neoproterozoic of Death Valley, California, USA. Geology, 45, 31-34. https://doi.org/10.1130/G38460.1

Le Heron, D.P., Busfield, M.E., Ali, D.O., Al Tofaif, S., Vandyk, T.M. 2018. The Cryogenian record in the southern Kingston Range, California: the thickest Death Valley succession in the hunt for a GSSP. Precambrian Research, 319, 158172. https://doi.org/10.1016/j.precamres.2017.07.017

Le Heron, D.P., Busfield, M.E., Ali, D.O., Vandyk, T., Tofaif, S., 2019. A tale of two rift shoulders, and two ice masses: the Cryogenian glaciated margin of Death Valley, California. In: Le Heron, D.P., Hogan, K.A., Phillips, E.R., Huuse, M., Busfield, M.E. Graham, A.G.C. (eds.), Glaciated Margins: The Sedimentary and Geophysical Archive. Geological Society, London, Special Publications, 475, 35-52. https://doi. org/10.1144/SP475.11

Li, Z.X., Li, X.H., Kinny, P.D., Wang, J., Zhang, S., Zhou, H., 2003. Geochronology of Neoproterozoic syn-rift magmatism in the Yangtze craton South China and correlation with other continents: evidence for mantle superplume that broke up Rodinia. Precambrian Research, 122, 85-109. https:// doi.org/10.1016/S0301-9268(02)00208-5

Li, Z.-X., Evans, D.A.D., Halverson, G.P., 2013. Neoproterozoic glaciations in a revised global palaeogeography from the breakup of Rodinia to the assembly of Gondwanaland. Sedimentary Geology, 294, 219-232. https://doi. org/10.1016/j.sedgeo.2013.05.016

Lund, K., Aleinikoff, J.N., Evans, K.V., Fanning, C.M., 2003. SHRIMP U-Pb geochronology of Neoproterozoic Windermere Supergroup, central Idaho: implications for rifting of western Laurentia and synchroneity of Sturtian glacial deposits. Geological Society of American Bulletin, 115, 349372. https://doi.org/10.1130/0016-7606(2003)115<0349:SUPGON $>2.0 . \mathrm{CO} ; 2$

Link, P.K., Christie-Blick, N., Devlin, W.J., Elston, D.P., Horodyski, R.J., Levy, M., Miller, J.M.G., Pearson, R.C., Prave, A., Stewart, J.H., Winston, D., Wright, L.A., Wrucke, C.T., 1993. Middle and late Proterozoic stratified rocks of the western U.S. Cordillera, Colorado Plateau and Basin Range Province. In Reed, J.C., et al. (eds.), Precambrian: Coterminous U.S. Geology of North America, v. C-2, 463-595. Geological Society of America, Boulder, Colorado. https://doi. org/10.1130/DNAG-GNA-C2.463

Ma, G., Lee, H., Zhang, Z., 1984. An investigation of the limits of the Sinian system in South China, Bulletin of the Yichang Institute of Geology and Mineral Resources. Chin., Acad., Geol. Sci., 8, 1-29.

Macdonald, F.A., Schmitz, M.D., Crowley, J.L., Roots, C.F., Jones, D.S., Maloof, A.C., Strauss, J.V., Cohen, P.A., Johnston, D.T., Schrag, D.P., 2010. Calibrating the Cryogenian. Science, 327, 1241-1243. https://doi/ 10.1126/science. 1183325

Mawson, D., 1949. The Elatina glaciation. A third occurrence of glaciation evidenced in the Adelaide System. Transactions of the Royal Society of South Australia, 73, 117-121. Mawson, D., Sprigg, R. C., 1950. Subdivision of the Adelaide System. Australian Journal of Science, 13, 69-72.

McDonough, M.R., Parrish, R.R., 1991. Proterozoic gneisses of the Malton Complex, near Valemount, British Columbia: $\mathrm{U}-\mathrm{Pb}$ ages and $\mathrm{Nd}$ isotopic signatures. Canadian Journal of Earth Science, 23, 1202-1216. https://doi.org/10.1139/ e91-108

MacLennan, S., Park, Y., Swanson-Hysell, N., Maloof, A., Schoene, B., Gebreslassie, M., Antilla, E., Tesema, T., Alene, 
M., Haileab, B., 2018. The arc of the Snowball: U-Pb dates constrain the Islay anomaly and the initiation of the Sturtian glaciation. Geology, 46, 539-542. https://doi. org/10.1130/G40171.1

Merdith, A.S., Collins, A.S., Williams, S.E., Pisarevsky, S., Foden, J.D., Archibald, D.B., Blades, M.L., Alessio, B.L., Armistead, S., Plavsa, D., Clark, C., Müller, R.D., 2017. A fullplate global reconstruction of the Neoproterozoic. Gondwana Research 50, 84-134. https://doi.org/10.1016/j. gr.2017.04.001

Miller, N.R., Alene, M., Sacchi, R., Stern, R.J., Conti, A., Kröner, A., Zuppi, G., 2003. Significance of the Tambien Group (Tigrai, N. Ethiopia) for Snowball Earth Events in the Arabian-Nubian Shield. Precambrian Research, 121, 263-283. https://doi.org/10.1016/S0301-9268(03)00014-7

Partin, C.A., Sadler, P.M., 2016. Slow net sediment accumulation sets snowball Earth apart from all younger glacial episodes. Geology, 44, 1019-1022. https://doi.org/10.1130/ G38350.1

Powell, R.D., Cooper, J.M., 2002. A glacial sequence stratigraphic model for temperate, glaciated continental shelves. In: Dowdeswell, J.A., O'Cofaigh, C. (eds.), Glacier-influenced sedimentation on high-latitude continental margins. Geological Society of London, Special Publication, 203, 215-244. https://doi.org/10.1144/GSL. SP.2002.203.01.12

Prave, A. R., 1999. Two diamictites, two cap carbonates, two $\delta 13 C$ excursions, two rifts: The Neoproterozoic Kingston Peak Formation, Death Valley, California. Geology, 27, 339324. https://doi.org/10.1130/0091-7613(1999)027<0339:TDTCCT>2.3.CO;2

Preiss, W.V., 1987, (ed.). The Adelaide Geosyncline-late Proterozoic stratigraphy, sedimentation, paleontology and tectonics: South Australia Geology Survey Bulletin, 53, 438.

Preiss, W.V., Drexel, J.F. Reid, A.J., 2009. Definition and age of the Kooringa Member of the Skillogalee Dolomite: host for Neoproterozoic (c. $790 \mathrm{Ma}$ ) porphyry-related copper mineralisation at Burra. MESA Journal, 55, 19-33.

Preiss, W.V., Gostin, V.A., McKirdy, D.M., Ashley, P.M., Williams, G.E., Schmidt, P.W., 2011. The glacial succession of Sturtian age in South Australia: the Yudnamutana Subgroup. In: Arnaud, E., Halverson, G.P., Shields-Zhou, G. (eds.), The Geological Record of Neoproterozoic Glaciations. Geological Society, London, Memoir 36, 701-712. https://doi. org/10.1144/M36.69

Rooney, A.D., Chew, D.M., Selby, D., 2011. Re-Os Geochronology of the Neoproterozoic Cambrian Dalradian Supergroup of Scotland and Ireland: Implications for Neoproterozoic stratigraphy, glaciations and Re-Os systematics. Precambrian Research, 185, 202-214. https://doi. org/10.1016/j.precamres.2011.01.009

Rooney, A.D., Macdonald, F.A., Strauss, J.V., Dudás, F.Ö., Hallmann, C., Selby, D., 2014. Re-Os geochronology and coupled Os-Sr isotope constraints on the Sturtian snowball Earth. Proceedings of the National Academy of Science, 111, 51-56. https://doi.org/10.1073/pnas.1317266110

Rooney, A.D., Strauss, J.V., Brandon, A.D. Macdonald, F.A., 2015. A Cryogenian chronology: two long-lasting synchronous Neoproterozoic glaciations. Geology, 43, 459-462. https://doi.org/10.1130/G36511.1

Ross, G.M., Villeneuve, M.E., 1997. U-Pb geochronology of stranger stones in Neoproterozoic diamictites, Canadian Cordillera: implications for provenance and age of deposition. Geological Survey of Canada, Current Research 1997F, 141-155. https://doi/10.4095/209100

Schaefer, B.F., Burgess, J.M., 2003. Re-Os isotopic age constraints on deposition in the Neoproterozoic Amadeus Basin: implications for the "snowball Earth". Journal of the Geological Society of London 160, 825-828. https://doi. org/10.1144/0016-764903-050

Shields, G.A., Halverson, G.P., Porter, S.M., 2018. Descent into the Cryogenian. Precambrian Research, 319, 1-5. https:// doi.org/10.1016/j.precamres.2018.08.015

Strauss, J.V., Rooney, A.D., Macdonald, F.A., Brandon, A.D., Knoll, A.H., 2014. 740 Ma vase-shaped microfossils from Yukon, Canada: Implications for Neoproterozoic chronology and biostratigraphy: Geology, 42, 659-662. https:// doi.org/10.1130/G35736.1

Spence, G.H., Le Heron, D.P., Fairchild, I.J., 2016. Sedimentological perspectives on climatic, atmospheric and environmental change in the Neoproterozoic Era. Sedimentology, 63, 253-306. https://doi.org/10.1111/sed.12261

Tadesse, T., Hoshimo, M., Suzuki, K., lizumi, S., 2000. Sm-Nd, $\mathrm{Rb}-\mathrm{Sr}$ and Th- $\mathrm{U}-\mathrm{Pb}$ zircon ages of syn- and post-tectonic granitoids from the Axum area of Northern Ethiopia. Journal of Africa Earth Sciences, 30, 313-327. https://doi. org/10.1016/S0899-5362(00)00022-1

Thompson, M.D., Bowring, S.A., 2000. Age of the Squantum "tillite", Boston Basin, Massachusetts: U-Pb zircon constraints on terminal Neoproterozoic glaciation. American Journal of Science, 300, 630-655. 10.2475/ajs.300.8.630

Tofaif, S., Vandyk, T., Le Heron, D.P., Melvin, J. 2019. Glaciers, flows, and fans: Origins of a Neoproterozoic diamictite in the Saratoga Hills, Death Valley, California. Sedimentary Geology, 385, 79-95. https://doi.org/10.1016/j.sedgeo.2019.03.003

Tollo, R.P., Aleinkoff, J.N., 1996. Petrology and U-Pb geochronology of the Robertson River igneous suite, Blue Ridge Province, Virginia- evidence for multistage magmatism associated with an early episode of Laurentian rifting. American Journal of Science, 296, 1045-1090. https:// doi/10.2475/ajs.296.9.1045

Williams, G.E., Gostin, V.A., McKirdy, D.M., Preiss, W.V., Schmidt, P.W., 2011. The Elatina glaciation (late Cryogenian), South Australia. In: Arnaud, E., Halverson, G.P., Shields-Zhou, G. (eds.), The Geological Record of Neoproterozoic Glaciations. Geological Society, London, Memoir 36, 713-721. https://doi.org/10.1144/M36.70

Xu, B., Jang, P., Zheng, H., Zou, H., Zhang, L., Liu, D., 2005. $\mathrm{U}-\mathrm{Pb}$ zircon geochronology and geochemistry of Neoproterozoic volcanic rocks in the Tarim Block of northwestern China: Implications for the break up of Rodinia supercontinent and glaciations: Precambrian Research, 136, 107-123. https://doi.org/10.1016/j.precamres.2004. 09.007 
Xu, B., Xiao, S., Chen, Y., Li, Z-X., Song, B., Liu, D., Zhou, C., Yuan, $X ., 2009$. SHRIMP zircon U-Pb age constraints on Neoproterozoic Quruqtagh diamictites in NW China, Precambrian Research, 168, 247-258. https://doi.org/10.1016/j.precamres.2008.10.008

Yang, J., Xue, Y., Tao, X., 1994, Sm-Nd radiometric dating of the Doushantuo Formation, south China. Chinese Science Bulletin, 39, 65-68.

Yin, C., Tang, F., Liu, Y., Gao, L., Yang, Z., Wang, Z., Liu, P., Xing, Y., Song, B., 2005. New U-Pb zircon ages from the Ediacaran (Sinian) System in the Yangtze Gorges: Constraints on the age of Miaohe biota and Marinoan glaciation. Geological Bulletin of China, 24, 393-400.

Yin, C., Tang, F., Liu, Y., Gao, L., Liu, P., Xing, Y., Yang, Z., Wan, Y., Wang, Z., 2005. U-Pb zircon age from the base of the Ediacaran Doushantuo Formation in the Yangtze Gorges, South China: constraint on the age of Marinoan glaciation. Episodes, 28, 48-49.

Zhang, Q.R., Li, X.H., Feng, L.J., Huang, J., Song, B., 2008. A new constraint on the onset of Neoproterozoic glaciations in the Yangtze platform, South China. Journal of Geology, 116, 423-429.
Zhang, S., Jiang, G., Song, B., Kennedy, M.J., Christie-Blick, N., 2005. U-Pb sensitive high resolution ion microprobe ages from the Doushantuo Formation in China: constraints on late Neoproterozoic glaciations. Geology, 33, 473-476.

Zhang, S., Jiang, G., Han, Y., 2008. The age of the Nantuo Formation and Nantuo glaciation in south China. Terra Nova, 20, 289-294.

Zhang, S.H., Jiang, G.Q., Dong, J., Han, Y.G., Wu, H.C., 2008. New SHRIMP U-Pb age from the Wuqiangxi Formation of Banxi Group: Implications for rifting and stratigraphic erosion associated with the early Cryogenian (Sturtian) glaciation in south China. Science in China Series D: Earth Sciences, 51, 1537-1544.

Zhou, C., Tucker, R., Xiao, S., Peng, Z., Yuan, X., Chen, Z., 2004. New constraints on the ages of Neoproterozoic glaciations in south China. Geology, 32, 437-440.

Zhou, C., Huyskens, M.H., Lang, X., Xiao, S., Yin, Q.-Z., 2019. Calibrating the terminations of Cryogenian global glaciations. Geology, 47, 251-254.

Received: 24.9.2019

Accepted: 23.3.2020

Editorial Handling: Walter Kurz 